

Jurnal Sains Farmasi \& Klinis (p- ISSN: 2407-7062 | e-ISSN: 2442-5435)

diterbitkan oleh Ikatan Apoteker Indonesia - Sumatera Barat homepage: http://jsfkonline.org

\title{
Aktivitas Antioksidan dan Tabir Surya Ekstrak Etanol Daun Stroberi (Fragaria $x$ ananassa A.N. Duchesne)
}

\author{
\{Antioxidant and Sunscreen Activities of Ethanol Extract of Strawberry Leaves \\ (Fragaria $x$ ananassa A.N. Duchesne)\}
}

\author{
Widyastuti*, Ariya Eka Kusuma, Nurlaili, Fitriani Sukmawati \\ Akademi Farmasi Imam Bonjol Bukittinggi
}

\begin{abstract}
Keywords:
antioxidant,

strawberry leaves,

sunscreen
\end{abstract}

Kata Kunci:

antioksidan, daun

stroberi, tabir surya

\begin{abstract}
Strawberry fruit extract contains polyphenols compounds, which have antioxidant activity and may inhibit cancer cell growth. In this study attempted to see activity from leaves of strawberry (Fragaria $x$ ananassa A.N. Duchesne) does also have antioxidant activity and sunscreen. Antioxidant testing using the DPPH method with comparative of vitamin $C$. The result showed IC50 values of ethanol extract of the leaves of strawberries $363.551 \mathrm{ppm}$ and for vitamin C $33.573 \mathrm{ppm}$. On testing the activity as a sunscreen using spectrophotometric method wherein the ethanol extract of the leaves of strawberries have SPF values above 15 at a concentration of 175 ppm, which amounted to 20.090 with erythema percentage of 5.496 and 5.074 percentage by pigmentation. It can be concluded from the ethanol extract of leaves of strawberry has antioxidant activity and sunscreen.
\end{abstract}

ABSTRAK: Ekstrak buah stroberi mengandung senyawa polifenol yang mempunyai aktivitas antioksidan dan dapat menghambat pertumbuhan sel kanker. Pada penelitian ini dicoba untuk melihat aktivitas dari daun stroberi (Fragaria x ananassa A.N. Duchesne) apakah juga mempunyai aktivitas antioksidan dan tabir surya. Pengujian antioksidan menggunakan metode DPPH dengan pembanding vitamin C. Dari hasil penelitian didapatkan nilai IC50 ekstrak etanol daun stroberi sebesar 363,551 ppm dan untuk vitamin C sebesar 33,573 ppm. Pada pengujian aktivitas sebagai tabir surya menggunakan metode spektrofotometri dimana ekstrak etanol daun stroberi mempunyai nilai SPF diatas 15 pada konsentrasi 175 ppm, yaitu sebesar 20,090 dengan persentase eritema sebesar 5,496 dan persentase pigmentasi sebesar 5,074. Dari hasil penelitian dapat disimpulkan ekstrak etanol daun stroberi mempunyai aktivitas antioksidan dan tabir surya.

\section{PENDAHULUAN}

Tanaman stroberi (Fragaria $x$ ananassa) terdapat banyak mengandung manfaat bagi kesehatan. Buah stroberi kaya akan pigmen warna antosianin dan mengandung antioksidan tinggi. Antioksidan merupakan zat yang dapat melawan pengaruh bahaya dari radikal bebas. Pengujian antioksidan dari ekstrak air daun stroberi, blackberry dan raspberry didapatkan ekstrak air daun stroberi (Fragaria vesca L) menunjukkan antioksidan yang lebih besar dari yang lainnya. Stroberi merupakan tanaman obat yang kaya akan manfaat. Selain mengandung vitamin $\mathrm{C}$ dan asam elagik sebagai antioksidan ternyata stroberi juga mengandung vitamin $\mathrm{B} 1, \mathrm{~B} 2$ dan provitamin $\mathrm{A}$
*Corresponding Author: Widyastuti (Akademi Farmasi Imam Bonjol
Bukittinggi)

email:widya_apt161@yahoo.com
Article History:

Received: 14 Jan 2016 Accepted: 21 Jan 2016

Published: 01 Nov 2016 Available online: 21 Dec 2016 
yang dapat menghaluskan kulit dan membuat warna kulit menjadi cerah, bersih dan mencegah terjadinya keriput [1, 2, 3, 4].

Kulit keriput dapat disebabkan oleh radikal bebas dan sinar matahari. Lumatan daun stroberi yang dilumurkan pada wajah sangat bermanfaat untuk menegah pengeriputan kulit. Sinar matahari merupakan gelombang elektromagnetik yang menjadi sumber semua jenis sinar. Sinar matahari mempunyai efek yang merugikan bagi manusia, tergantung dari frekuensi dan lamanya sinar matahari mengenai kulit, intensitas matahari serta kepekaan seseorang. Dipermukaan bumi sinar matahari terdiri dari beberapa spektrum yaitu sinar infra merah, sinar tampak, sinar ultra violet (UV-A), sinar UV-B dan sinar UV-C yang sangat berbahaya karena memiliki energi yang sangat tinggi dan bersifat karsinogenik. Zat yang dapat mengurangi efek buruk sinar matahari atau sering disebut tabir surya. Selain dari bahan kimia tabir surya juga terdapat pada bahan alam. Kemampuan menahan sinar ultra violet (UV) dari tabir surya dinilai dengan Sun Protecting Factor $(\mathrm{SPF})[5,6$, 7].

Pengujian aktivitas antioksidan daun stroberi (Fragaria $x$ ananassa A.N. Duchesne) dan sebagai tabir surya belum diketahui, maka dari itu, dilakukan pengujian aktivitas antioksidan dengan metoda DPPH dengan menggunakan pembanding vitamin $\mathrm{C}$ dan pengujiaan aktivitas tabir surya dari ekstrak etanol daun stroberi dengan metode spektrofotometri. Penelitian ini bertujuan untuk mengetahui aktivitas antioksidan dan tabir surya ekstrak etanol daun stroberi (Fragaria $x$ ananassa A.N. Duchenes).

\section{METODE PENELITIAN}

\section{Alat dan Bahan}

Spektrofotometer UV-Vis Shimadzu Pharma 1700, alat gelas, vial, lumpang dan stamfer, waterbath, pipet mikro, timbangan digital, rotary evaporator, daun stroberi, pasir bersih, kloroform, asam sulfat pekat, reagen meyer, aquadest, $\mathrm{FeCl}_{3}$, norit, asetat anhidrat, etanol 96\%.

\section{Cara Kerja}

Daun stoberi dibersihkan, dirajang dan keringanginkan selama dua sampai tiga hari, dimaserasi dengan etanol $96 \%$, filtrat dipekatkan dengan menggunakan rotary evaporator. Ekstrak kental yang didapatkan dilakukan pengujian skrining fitokimia [8].

Penentuan Aktivitas Antioksidan Ekstrak [9, 10, 11]

$5 \mathrm{mg}$ DPPH dimasukkan kedalam labu ukur $250 \mathrm{ml}$ dan dilarutkan dalam pelarut etanol sehingga diperoleh larutan DPPH 20 ppm. Serapan larutan diukur dengan spektrofotometer UVVis dan didapatkan panjang gelombang serapan maksimum pada 516,5 nm dengan nilai absorbansi sebesar 0,560 .

Larutan uji dibuat dengan konsentrasi ekstrak 100, 200, 400, 600 dan 800 ppm. Sebagai pembanding digunakan Vitamin $\mathrm{C}$ dengan konsentrasi 10, 20, 30, 40 dan 50 ppm. Masingmasing larutan uji sebanyak $0,2 \mathrm{ml}$ ditambahkan $3,8 \mathrm{ml}$ larutan DPPH $20 \mu \mathrm{l} / \mathrm{ml}$ di dalam test tube, dilakukan juga pengujian blanko. Campuran didiamkan selama 30 menit pada suhu kamar dan pada ruangan yang terlindung dari cahaya. Absorbansinya diukur pada panjang gelombang $516,5 \mathrm{~nm}$, persentase penangkapan radikal bebas menggunakan persamaan:

\section{$\%=$ Absorban DPPH-Ansorban Sampel x 100\% Absorban DPPH}

Dari hasil yang didapat dibuat kurva persamaan regresi dan ditentukan nilai $\mathrm{IC}_{50}(50 \%$ Inhibitory Concentration) masing-masing untuk ekstrak dan vitamin C. Makin kecil nilai IC $_{50}$ makin tinggi aktivitas penangkapan radikal bebasnya. 
Penentuan Aktivitas Tabir Surya [12, 13, 14, 15]

Penentuan angka SPF dihitung dengan persamaan:

$$
S P F=\frac{\int_{m e}^{n e} \varepsilon_{\lambda} s_{\lambda} \cdot d \lambda}{\int_{m 00}^{56} \varepsilon_{\lambda} \cdot s_{\lambda} \cdot \tau_{\lambda}-d \lambda}
$$

Dimana dan adalah tetapan hubungan efek eritemogenik dengan intensitas radiasi pada $\lambda$ 290-350 nm, merupakan transmisi larutan uji. Nilai SPF ini berkisar antara o sampai 100, dan kemampuan tabir surya yang dianggap baik diatas 15. Penentuan persentase transmisi eritema dan pigmentasi dilakukan dengan konsentrasi ekstrak $100,125,150,175$ dan 200 ppm, lalu masingmasing diukur serapannya dengan menggunakan Spektrofotometer UV-Vis pada panjang gelombang yang dapat menimbulkan eritema yaitu 292,5-337,5 nm dan pigmentasi yaitu 292,5$372,5 \mathrm{~nm}$. Kategori aktivitas bahan tabir surya kemudian di nilai berdasarkan persentase eritema dan persentase pigmentasi.

\section{HASIL DAN DISKUSI}

Stroberi merupakan tanaman asli Benua Amerika tepatnya Negara Chili ini bermanfaat untuk kesehatan dan perawatan tubuh karena mengandung berbagai vitamin dan persenyawaan fenol. Ekstrak air daun Strawberry, Blackberry, dan Raspberry (Fragaria vesca L., Rubus fructicosus L., dan Rubus idaeus L.) sebagian besar mengandung senyawa katekin dan asam elagik, katekin merupakan senyawa polifenol $[1,16]$.

Pada penelitian yang dilakukan ekstrak etanol daun stroberi (Fragaria x ananassa A.N Duchesne) berupa cairan kental berwarna hijau kehitaman dan berbau khas daun stroberi, larut dalam air dan etanol. Hasil pengujian skrining fitokimia mengandung senyawa flavonoid dan fenolik. Hasil rendemen ekstrak dari daun kering sebesar 18\% dan susut pengeringan yang didapat dari ekstrak etanol daun stroberi adalah sebesar 7,82\%.

Pengujian aktivitas antioksidan ekstrak etanol daun stroberi didapatkan nilai IC $_{50}$ sebesar 363,551 ppm dan untuk Vitamin C sebesar 33,573 ppm. Besarnya aktivitas antioksidan ditandai dengan nilai $\mathrm{IC}_{50}$. Nilai $\mathrm{IC}_{50}$ merupakan konsentrasi sampel yang dapat meredam DPPH sebanyak $50 \%$. Berdasarkan nilai $\mathrm{IC}_{50}$ ekstrak maka ekstrak dikategorikan ke dalam antioksidan yang sangat rendah dan berdasarkan perbandingannya dengan Vitamin $\mathrm{C}$ dapat disimpulkan efek antioksidan ekstrak lebih rendah dari Vitamin C. Penelitian yang dilakukan Buricova et.al (2011) didapatkan kapasitas antioksidan ekstrak air daun stroberi (Fragaria vesca L) sebesar 73,6 - 88,9\% dibandingkan esktrak air daun teh hijau dan dapat disimpulkan kapasitas antioksidan daun stroberi hampir menyamai kapasitas antioksidan daun teh hijau. Dari hasil yang didapatkan maka aktivitas ekstrak pada penelitian lebih rendah daripada yang didapatkan oleh Buricova et.al. Kapasitas antioksidan ekstrak daun stroberi dapat dipengaruhi oleh spesies, keadaan tempat tumbuh, iklim dan serangan hama tanaman [17].

Antioksidan merupakan suatu zat yang memiliki kemampuan untuk memperlambat proses oksidasi yang berdampak negatif di dalam tubuh seperti merusak sel sehingga mempercepat penuaan dini pada kulit, mengakibatkan kanker, penyakit jantung, dan sebagainya. Antioksidan yang terdapat pada tanaman digunakan untuk menangkal radikal bebas, tanaman yang dapat dijadikan antioksidan tersebut biasanya mengandung senyawa karotenoid, flavonoid, polifenol dan sulfide alil. Antioksidan ini banyak ditemukan pada buah-buahan, sayuran dan bijibijian. Warna buah-buahan dan sayuran merupakan pigmen yang bermanfaat sebagai antioksidan. Pigmen warna merah mengandung likopen dan antosianin, pigmen warna biru atau ungu juga mengandung antosinin yang bermanfaat untuk 
Tabel 1. Persentase Inhibisi terhadap DPPH 20 ppm

\begin{tabular}{|c|c|c|c|c|}
\hline \multirow{2}{*}{ No } & \multicolumn{2}{|c|}{ Ekstrak etanol daun stroberi } & \multicolumn{2}{|c|}{ Vitamin $C$} \\
\hline & Konsentrasi (ppm) & Persentase (\%) & Konsentrasi (ppm) & Persentase (\%) \\
\hline 1 & 100 & $24,821 \%$ & 10 & 19,893 \\
\hline 2 & 200 & $33,214 \%$ & 20 & 29,535 \\
\hline 3 & 400 & $55,892 \%$ & 30 & 45,428 \\
\hline 4 & 600 & $75,357 \%$ & 40 & 58,036 \\
\hline 5 & 800 & $86,607 \%$ & 50 & 73,036 \\
\hline
\end{tabular}

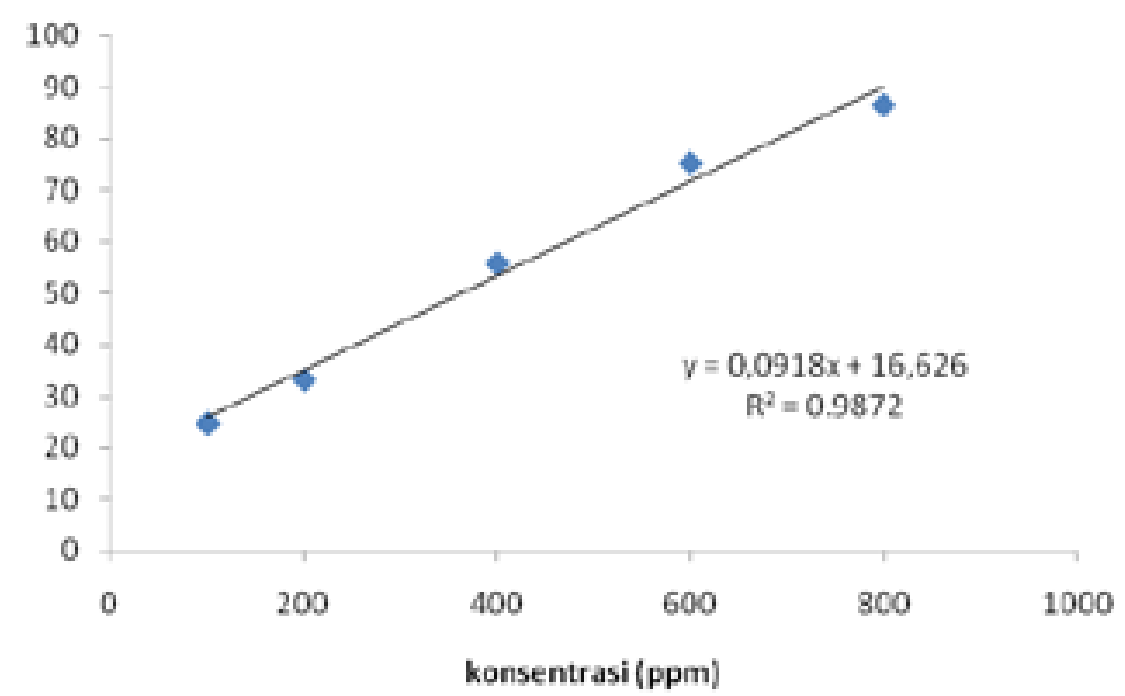

Gambar 1. Kurva Regresi Persentase Inhibisi Ekstrak Terhadap DPPH

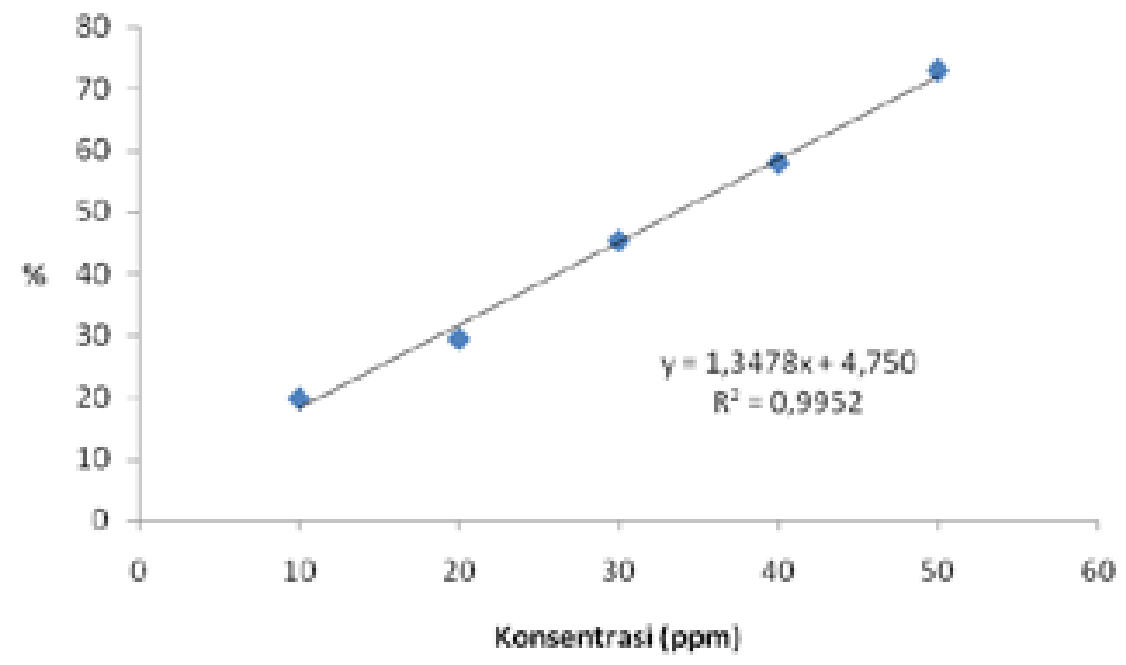

Gambar 2. Kurva Regresi Persentase Inhibisi Vitamin C terhadap DPPH

melindungi sel tubuh dari kerusakan, membuat awet muda dan meningkatkan daya ingat. Antioksidan dari tanaman ini dapat membantu peremajaan selsel tubuh sehingga sel tubuh dapat beregenerasi sehingga mencegah penuaan dini dan membuat awet muda. Stroberi mengandung antiokidan yang tinggi dimana antioksidan tersebut dapat mengurangi penyakit kronis salah satunya kanker hati $[18,19,20]$.

Antioksidan dapat membantu peremajaan sel- 
sel tubuh sehingga sel tubuh dapat beregenerasi. Tumor dan kanker kulit merupakan penyakit kulit yang diakibatkan oleh paparan radikal bebas yang berasal dari sinar matahari maupun polutan udara, faktor lain yang mempengaruhi yaitu terpapar zat karsinogen, faktor genetik dan jenis kulit terutama kulit putih. Antioksidan dapat melindungi kulit dari efek negatif radikal bebas yang dapat mengakibatkan penyakit kulit. Jenis antioksidan yang dapat bermanfaat untuk kulit yaitu vitamin A, vitamin E, karotenoid, betakaroten, likopen, polifenol, flavonoid dan lutein [18].

Pada skrining fitokimia daun stroberi (Fragaria $x$ ananassa A.N Duchesne) mengandung senyawa flavonoid, sehingga adanya kemungkinan mempunyai aktivitas sebagai tabir surya. Tabir surya mengandung senyawa yang melindungi kulit dari sengatan sinar matahari atau sinar UV dengan cara menghamburkan cahaya secara efektif dengan mengabsorbsinya. Salah satu senyawa kimia yang aktif sebagai tabir surya adalah senyawa fenolik $[21,22]$.

Hasil penelitian menunjukkan ekstrak etanol daun stroberi mempunyai nilai SPF diatas 15 pada konsentrasi 175 ppm sebesar 20,090 dengan persentase eritema sebesar 5,496 dan persentase pigmentasi sebesar 5,074, hasil selengkapnya dapat dilihat pada tabel 2 .

Tabir surya pada seluruh konsentrasi dikategorikan sebagai proteksi ekstra berdasarkan persentase eritema dan kategori sunblock berdasarkan persentase pigmentasi. Penyinaran matahari yang sedang secara psikologi dan fisiologi akan menimbulkan rasa nyaman dan sehat. Sengatan matahari yang berlebihan adalah karsinogenik, karena bahaya yang disebabkan

Tabel 1. Kategori Penilaian Tabir Surya

\begin{tabular}{|c|c|c|c|c|c|}
\hline \multirow{2}{*}{$\begin{array}{c}\text { Konsentrasi } \\
(\mu g / m l)\end{array}$} & \multicolumn{2}{|c|}{ Persentase Transmisi } & \multicolumn{2}{|c|}{ Persentase Transmisi } & \multirow{2}{*}{$\begin{array}{l}\text { Nilai } \\
\text { SPF }\end{array}$} \\
\hline & Eritema & Kategoripenilaian & Pigmentasi & Kategori penilaian & \\
\hline 100 & 2,719 & proteksi ekstra & 2,589 & Sunblock & 4,753 \\
\hline 125 & 3,366 & proteksi ekstra & 3,172 & Sunblock & 8,511 \\
\hline 150 & 4,500 & proteksi ekstra & 4,187 & Sunblock & 14,093 \\
\hline 175 & 5,496 & proteksi ekstra & 5,074 & Sunblock & 20,090 \\
\hline 200 & 6,341 & proteksi ekstra & 5,844 & Sunblock & 26,121 \\
\hline
\end{tabular}

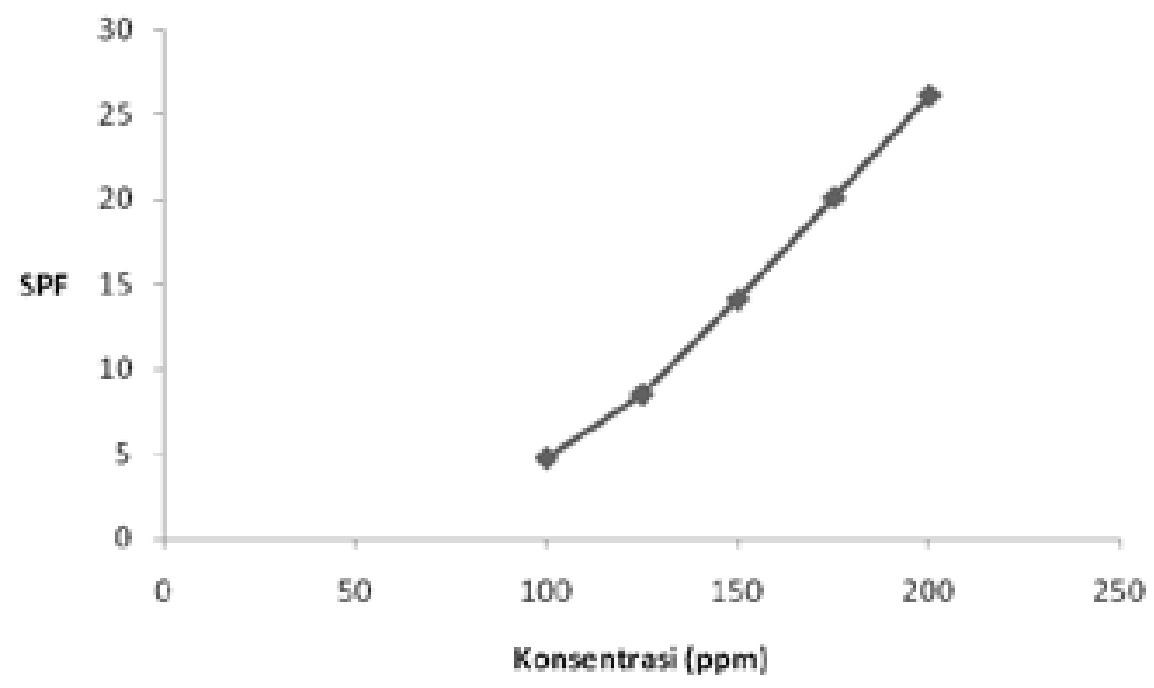

Gambar 3. Kurva Nilai SPF Ekstrak 
oleh penyinaran matahari, dianjurkan penggunaan bahan pelindung, misalnya tabir surya [23].

Penyinaran ultraviolet dengan panjang gelombang diatas $330 \mathrm{~nm}$ dapat menyebabkan kulit menjadi kecoklatan. Eritema timbul bersamaan dengan warna coklat. Faktor perlindungan kulit secara alami terhadap sengatan surya ialah dengan penebalan stratum korneum dan pigmentasi kulit. Nyeri akan timbul pada kulit yang tidak terlindung setelah penyinaran matahari. Tabir surya digunakan untuk maksud membaurkan atau menyerap secara efektif cahaya matahari, terutama daerah emisi gelombang ultraviolet dan inframerah, sehingga dapat mencegah terjadinya gangguan kulit karena cahaya matahari [23].

\section{KESIMPULAN}

Dari penelitian yang dilakukan dapat diambil kesimpulan ekstrak etanol daun stroberi mempunyai aktivitas antioksidan dengan nilai IC50 sebesar 363,551 ppm dan mempunyai aktivitas sebagai tabir surya dengan nilai SPF 20,090 pada konsentrasi 175 ppm.

\section{DAFTAR PUSTAKA}

1. Buricova, L., Andjelkovic M., Cermakova A., Reblova Z., Jurcek O., Kolehmainen E., Verhe R., \& Kvasnicka F. (2011). Antioxidant Capacity and Antioxidants of Strawberry, Blackberry and Raspberry Leaves. Czech Journal Food Science, 29(2), 181189.

2. Rohmayati, M. (2013). Budidaya Stroberi Dilahan Sempit. Infra Pustaka. Jakarta.

3. Cahyono, B. (2011). Sukses Budidaya Stroberi di Pot dan Perkebunan. Lily Publisher. Yogyakarta.

4. Gunawan, L. W. (2003). Stroberi. Penebar Swadaya. Jakarta.

5. Wasitaatmadja, S. M. (1997). Penuntun Ilmu Kosmetik dan Medik. UI-Pres. Jakarta.

6. Satiadarma, H., \& Suyoto. (1986). Kesehatan Kulit dan Kosmetika, Andi Offset. Yogyakarta.
7. Budiana, N.S. (2013). Buah Ajaib Tumpas Penyakit. Penyebar Swadaya. Jakarta

8. Djamal, R. (2010). Kimia Bahan Alam Prinsip-Prinsip Dasar Isolasi dan Identifikasi. Universitas Baiturrahmah. Padang.

9. Molyneux, P. (2004). The Use of The Stable Free Radical Diphenylpicrylhydrazyl (DPPH) for Estimating Antioxidant Activity. Songklanarin Journal Science Technology, 26(2), 211219.

10. Pratama, B.Y., Alen, Y., \& Bakhtiar A. (2013). Uji Antioksidan dan Penilaian Organoleptis Empat Varietas Teh Daun Gambir (Uncaria gambir [Hunter] Roxb). Proseding Paper Semnas TOI. XLIV. Padang

11. Rastuti, U., \& Purwati. (2012). Uji AntioksidanEkstrak Daun Kalba (Albizia falcataria) dengan Metode DPPH (1,1-difenil-2pikrilhidrazil) dan Identifikasi Senyawa Metabolit Sekundernya. Molekul, 7(1), 33-42.

12. Wungkana, I., Suryanto, E., \& Momuat, L. (2013). Aktivitas Antioksidan dan Tabir Surya Fraksi Fenolik dari Limbah Tongkol Jagung. Pharmacon Jurnal IImiah Farmasi, 2(4), 149-155.

13. Fatmawati, A., Ermina, P., Mufidah \& Sartini. (2006). Uji Aktivitas Ekstrak Etanol Temugiring (Curcuma heyneana Val.) Sebagai Bahan Tabir Surya, Majalah Farmasi dan Farmakologi, 10(2), 46-49.

14. Agustin, R., Oktadefitri, Y., \& Lucida, H. (2013). Formulasi Krim Tabir Surya dari Kombinasi Etil p- Metoksinamat dengan Katekin. Prosiding Seminar Nasional Perkembangan Terkini Sains Farmasi dan Klinik III. Padang

15. Mokodompit, A. N., Edy, H.J., \& Wiyono, W. (2013). Penentuan Nilai Sun Protective Faktor (SPF) Secara In Vitro Krim Tabir Surya Ekstrak Etanol Kulit Alpukat. Pharmacon Jurnal IImiah Farmasi, 2(3), 83-85.

16. Prihatini, N. (2004). Seri Tanaman Buah-buahan Pembudidayaan Stroberi. Karya Putra Darwati. Bandung.

17. Luo, Y., Tang, H., \& Zhang, Y. (2011). Production of Reactive Oxygen Species and Antioxidant Metabolism about Strawberry Leaves to Low Temperatures. Journal of Agricultural Science, 3(2), 89-96.

18. Irmawati, (2014). Keajaiban Antioksidan. Penerbit Padi. Jakarta.

19. Winarsi, H. (2007). Antioksidan Alami \& Radikal Bebas, Kanisius, Yogyakarta.

20. Meyers, K.J., Watkins, C.B., Prits, M.P., \& Liu, R.H., (2003). Antioxidan and Antiproliferative Activities of Strawberries. Journal of Agricultural and Food Chemistry, 51(23), 6887-6892.

21. Conrad, L. I. (1976). The Evaluation of a Sunscreening Agent for Safety and Activity. Journal of The Society of Cosmetic Chemist, 27, 87-107.

22. Gandjar, I. G., A. Rohman. (2012). Analisis Obat secara Spektrofotometri dan Kromatografi. Pustaka Pelajar, Yogyakarta.

23. Anonim. (1985). Formularium Kosmetika Indonesia. Departemen Kesehatan Republik Indonesia. Jakarta 